\title{
Dietetics in Medieval Islamic Culture
}

\author{
DAVID WAINES*
}

\section{The Classical Background}

The origins of dietetics understood as "the systematic control of food and drink in order to conserve health or combat disease" may be traced back to the Hippocratic Corpus, written chiefly between 430 and $330 \mathrm{BC}$. In Tradition in medicine the author argues that in the beginning man must have eaten the same food as the animals, that is, the produce of the earth, fruits, vegetables and grass. This diet of raw food caused many to suffer greatly and over time ways were discovered of preparing food better suited to man's natural constitution.

Thus, they took wheat and wetted it, winnowed it, ground it, sifted it, and then mixed it and baked it into bread, and likewise made cakes from barley. They boiled and baked and mixed and diluted the strong raw foods with the weaker ones and subjected them to many other processes, always with a view to man's nature and his capabilities. They knew that if strong food was eaten the body could not digest it and thus it would bring about pain, sickness and death, whereas the body draws nourishment and thus grows and is healthy from food it is able to digest.

The writer then asks what more fitting name could be given to such research and discovery than medicine which was "founded for the health, preservation and nourishment of man and to rid him of that diet which caused pain, sickness and death"? ${ }^{2}$ Therefore, medicine, as Foucault has suggested, came into being as an "appropriate 'diet' for the sick, emerging from a search for the specific regimen for their condition. In this tale of genesis, it is dietetics that appears to be initial; it gives rise to medicine as one of its particular applications."3

On the other hand, the crucial activity without which neither medicine nor dietetics would have been possible were the techniques and processes of transforming raw foodstuffs into more palatable and digestible matter, namely, cooking. Placing this mundane activity in its proper context, we could say that if the outcome of such primitive methods of research and discovery can be labelled the art of medicine, then certainly the "experimental" practice upon which it was based could be called the culinary art, a cluster of activities no less essential and ennobling than medicine in their mutual pursuit of health, preservation and nourishment. Without explicitly naming the latter art, the Hippocratic author goes on to ask:

*Professor David Waines, Head, Department of Religious Studies, Lancaster University, Lancaster, LAl 4 YG.

The author wishes to thank the Wellcome Trust for the award of a Research Leave Fellowship which has made the completion of this study possible.

${ }^{1}$ See W F Bynum, E J Browne, and Roy Porter (eds), Dictionary of the history of science, London, Macmillan, 1981, p. 102.

${ }^{2}$ Hippocratic writings, ed. with introduction by G E R Lloyd, Harmondsworth, Penguin [1950], 1983, p. 72 (translation of Tradition in medicine, pp. 70-86, by J Chadwick and W M Mann).

${ }^{3}$ Michel Foucault, The history of sexuality, vol. 2, The use of pleasure, London, Penguin, [1985] 1992, p. 99. 


\section{Dietetics in Medieval Islamic Culture}

What ... is the difference in intention between the man who discovered the mode of life suitable for the sick, who is called a physician and admitted to be a scientist, and him who, from the beginning, discovered the way to prepare the food we now eat instead of the former wild and animal-like diet? I can see no difference; the discovery is one and the same thing. ${ }^{4}$

Although he then insists that the physician is the forerunner of the cook, what he accurately identified was a medico-culinary tradition, or rather, a tradition in which medical and culinary concerns for food and nourishment were assumed to be closely joined. It is in this broader sense that dietetics should properly be viewed.

The survival of the medico-culinary tradition in Greek is alluded to in the Philosophers at dinner, written around $\mathrm{AD} 200$ by Athenaeus, a contemporary of Galen. In a passing reference to a prized Lydian sauce, Athenaeus notes the names of more than a dozen compilers of cookbooks who mention it, five of whom were also medical writers. ${ }^{5}$ Unfortunately, nothing of the cookbooks has survived. What Athenaeus has preserved, however, are fragments of a poem on food entitled The life of luxury by Archestratus (third century $\mathrm{BC}){ }^{6}$ As depicted by the poet, the luxury food par excellence was fish. ${ }^{7}$ Eighty per cent of the sixty-two fragments deal with various desirable species and where to procure them; only a quarter suggest methods for their preparation and none mentions any dietetic use for a preparation. On the culinary side as well, the single extant recipe collection in Latin is attributed to one Apicius who is thought to have lived in the first century AD, at the time of Tiberius (d. $37 \mathrm{AD}){ }^{8}$ Of the more than 400 recipes a mere handful reflect a specific dietetic purpose. For example, one preparation is recommended for an upset stomach or to facilitate digestion; another suggests a vegetable broth with a laxative property. ${ }^{9}$

Galen of Pergamum (129 to c. 200/216), ${ }^{10}$ the great successor to and commentator upon the Hippocratic Corpus, is a fundamental source for information on food and diet in the classical world; in the standard printed edition of his writings, dietetics fill several hundred pages, to which could be added a small work On slimming diets. Moreover, his formulation of what constituted a healthy life was to survive to the threshold of the modern period. Apart from the Hippocratic Corpus, Galen's chief sources on dietetics were authors writing around the year 300 BC, after which there was, in Nutton's graphic p. 74.

${ }^{4}$ Hippocratic writings, op. cit., note 2 above,

$5 \mathrm{~J}$ Wilkins and S Hill, 'The sources and sauces of Athenaeus', in J Wilkins, D Harvey, and M Dobson (eds), Food in Antiquity, Exeter University Press, 1995, pp. 429-38, on p. 431.

${ }^{6}$ Archestratus, The life of luxury: Europe's oldest cookery book, trans. with introduction and commentary by J Wilkins and S Hill, Totnes, Prospect Books, 1994.

${ }^{7}$ See also, J Wilkins, 'Social status and fish in Greece and Rome', in G Mars and V Mars (eds), Food, culture and history, London, The London Food Seminar, 1993, vol. 1, pp. 191-203.

${ }^{8}$ The Roman cookery book, trans. with introduction by B Flower and E Rosenbaum, London, Harrap, [1958] 1980. The translators state that the book, a fourth- or fifth-century work by an anonymous compiler, is a composite work derived from several sources, including Apicius.

${ }^{9}$ Ibid., pp. 59, 73-5, 87. The translators argue that these must come from earlier medical writings, which need not be so. Moreover, there seems to be no good evidence for their statement that recipes containing precise quantities of ingredients come from a Greek dietetic cookbook. First, precise measurements of ingredients are not a sure sign of dietetic intent, and second, the source could be as much Roman as Greek. See also the recipe, p. 215 , which is dietetic but contains no measurements of ingredients.

${ }^{10}$ For an excellent, brief account of his life and achievements, see Vivian Nutton, 'Roman medicine, $250 \mathrm{BC}$ to $\mathrm{AD} 200$ ', in L I Conrad, et al., The western medical tradition, Cambridge University Press, 1995, pp. 58-70. 


\section{David Waines}

phrase, "a black hole" until Galen's own time in the second century AD. The reason for this, Nutton suggests, is that by about $250 \mathrm{BC}$, in Alexandria, the classical canon of medical authors had already been established. The winners' views survived; the losers, like Diphilos, were left struggling for continued recognition. As a result, "[a]uthors would thus in general be aware only of the classics and the writings of contemporaries or near contemporaries, and they had little chance of filling in the gaps of knowledge. Hellenistic dietetics seem destined, alas, to remain a mystery." 11 Galen himself remained influential in medical thought in general, for by AD 500 in the Alexandrian school where he had once studied two sets of texts were offered on the syllabus, Hippocratic tracts largely approved of by Galen and a canon of sixteen books, admittedly only a tiny portion of his lifelong output. $^{12}$ In the following period, during the sixth and seventh centuries, there appears to have been a decline in the influence of the Greek medical tradition as the Eastern Mediterranean world underwent profound changes. It was into this changing and changed world that the religious culture of Islam emerged and expanded. ${ }^{13}$

\section{The Origin and Emergence of an Arabic Medico-Culinary-Dietetic Tradition}

Arabic medical writing commenced in the early eighth century during the creative and dynamic formative period of the Islamic community. A translation movement with its centre in Baghdad, the dynastic capital of the 'Abbasid Caliphs, introduced to an Arabic reading audience the medical works of the Hippocratic Corpus and those of Galen. Yet not only the two great canons of Greek medical thought found their way into Arabic in this way. For example, many works of lesser ranking figures such as Rufus of Ephesus, active at the end of the first century $\mathrm{AD}$, survive only in Arabic translation. ${ }^{14}$ The openness to Greek science shown by both the translators and their patrons was, in Goodman's words, "neither passive nor undirected but ... motivated from the start by an active and witting search for solutions to pragmatic problems." 15 And, he adds, pragmatism "insensibly but inexorably . . . breeds academic expertise, the drive to completeness, of scholarship or system", ${ }^{16}$ which resulted in the annexation of Greek medical science to Arabic-Islamic cultural domains. Moreover, according to one scholarly view, it led also to a "systematic revival of Greek humoral medicine". ${ }^{17}$ Representative of the movement as a whole were the Nestorian Hunayn b. Ishāq (d. 873) and his disciples, among whom were counted his

\footnotetext{
11 Vivian Nutton, 'Galen and the traveller's fare', in Wilkins, Harvey, and Dobson (eds), op. cit., note 5 above, pp. 359-70, on p. 362.

12 Nutton, op. cit., note 10 above, p. 81 . The author notes, p. 87, that one of Galen's works, a dietetic text On the preservation of health, "does not appear to have formed part of the canon before the Muslim period".

${ }^{13}$ L I Conrad, 'The Arab-Islamic medical tradition', in Conrad, et al., op. cit., note 10 above, pp. 93-138, especially at pp. 99-104.

${ }^{14} \mathrm{~F}$ Sezgin, Geschichte des Arabischen Schrifttums, Leiden, Brill, 1970, vol. 3, pp. 64-8, lists sixty of his works. Translations into Arabic of all the Greek medical sources are found on pp.
}

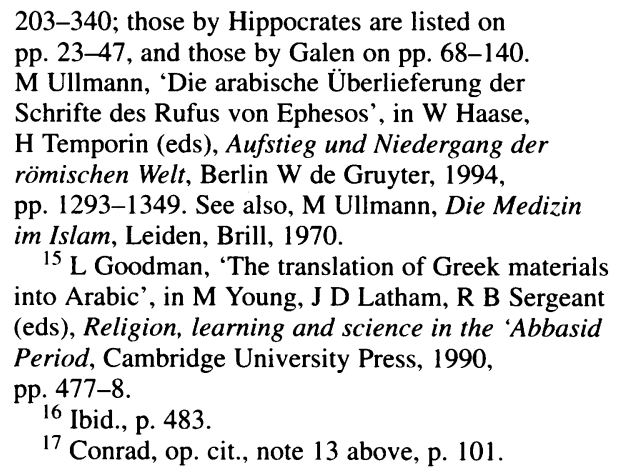

${ }^{15} \mathrm{~L}$ Goodman, 'The translation of Greek materials into Arabic', in M Young, J D Latham, R B Sergeant (eds), Religion, learning and science in the 'Abbasid Period, Cambridge University Press, 1990,

${ }^{17}$ Conrad, op. cit., note 13 above, p. 101. 


\section{Dietetics in Medieval Islamic Culture}

son and nephew. Hunayn claims to have translated into Arabic (or Syriac) nearly one hundred of Galen's works on his own and supervised the translation of many other medical works. Included among his own translations was Galen's dietetic tract entitled Kitāb al-aghdhiyya, on the property of foodstuffs. ${ }^{18}$ Among those who benefited early from the translators' labours while making original contributions of their own was the famous physician, medical writer and researcher, Abū Bakr Muhammad b. Zakariyya alRāzī (d. 925) known in Europe as Rhazes. He wrote several works on dietetics, including Kitāb manāfi ' al-aghdhiyya wa daf' madarriha, 'The book on the benefits of foodstuffs and avoidance of their harmful effects' ${ }^{19}$ Al-Rāzī's contemporary, Abū Ya'qūb Isḥāq b. Sulaymān al-Isrā'îlī (d. 932) also wrote a large dietetic treatise. ${ }^{20}$ More will be said of these works below.

Parallel with the activities of both the translation movement and the first original efforts of medical writers were signs of an emergent high culinary tradition expressed in Arabic and centred in Baghdad. The origins of this tradition are still somewhat obscure. ${ }^{21}$ The earliest extant culinary manual, Kitāb al-țabikh, compiled by one Ibn Sayyār al-Warrāq (of whom nothing is otherwise known) belongs to the late tenth century although it contains evidence of a high culinary culture dating from the early ninth century. ${ }^{22} \mathrm{An}$ interest in gastronomy appears to have been a pastime of various patrician personalities, including several princes of the ruling 'Abbasid house. This is reflected in recipe compilations made either by the concerned individual himself or by others in his name. The activity then spread among the bourgeois sectors of urban Muslim society, creating a "great" written cooking tradition in Arabic distinct from the unrecorded practices of the plebeian population, both urban and rural.

While this may have all the appearances of a gastronomic "new wave", 23 it is more likely to have been a revival of what was, perhaps, the oldest high culinary tradition in history. Babylonian cuneiform texts containing "the most ancient recipes of all" are possibly, according to their translator Jean Bottéro, of southern Mesopotamian provenance (in the area of Larsa) and date from the seventeenth century ВС. $^{24}$ Some recipes have the same concise, formulaic style of those found in Apicius. But there are differences in the styles of cooking; whereas in Apicius the key feature of the culinary art was the sauce made to accompany a main ingredient such as chicken or fish, ${ }^{25}$ the Babylonian art for

\footnotetext{
18 Sezgin, op. cit., note 14 above, p. 253 , no. 5.

${ }^{19}$ Abū Bakr Muhammad b. Zakariyya al-Rāzī, Kitāb manāfi ' al-aghdhiyya wa daf ' madarriha, Cairo, Bulaq, 1885. See also ibid., pp. 278-94 for his works; numbers $17,19,20,29,30,33,41,42$, and 68 are those related to dietetics. See also the brief discussion of his thought and medical writings by A Z Iskandar, 'al-Razi', in Young, et al. (eds), op. cit., note 15 above, pp. 370-7.

${ }^{20}$ Abū Ya qū Isḥāq b. Sulaymān al-Isrā'î̀i, Kitāb al-aghdhiyya, has been published in facsimile form by F Sezgin, Frankfurt am Main, Institute for the History of Arab-Islamic Science, 4 vols. in three, 1986. See also idem., in Sezgin, op. cit., note 14 above, p. 296, number 2.

${ }^{21}$ See the introduction to D Waines, In a caliph's kitchen, London, Riyad el-Rayyes, 1989.
}

\footnotetext{
22 Ibn Sayyār al-Warrāq, Kitāb al-țabikh, ed. Kaj Ohrnberg and Sahban Mroueh, Studia Orientalia, 60, Helsinki, Finnish Oriental Society, 1987.

${ }^{23}$ This is the argument I developed in op. cit., note 21 above, pp. 11-15 but now needs revising along the lines presented here. Cf. also, P Heine, Kulinarische Studien: Untersuchungen zur Kochkunst im arabisch-islamischen Mittelalter mit Rezepten, Franz Steiner, 1988; aa. vv., La médecine au temps des califes, Paris, Institut du monde arabe, 1996, pp. 173-83.

24 Jean Bottéro, 'The most ancient recipes of all', in Wilkins, Harvey, and Dobson (eds), op. cit., note 5 above, pp. 248-55.

25 Jon Solomon, 'The Apician sauce-ius Apicianum', in Wilkins, Harvey, and Dobson (eds), op. cit., note 5 above, pp. 115-31.
} 


\section{David Waines}

simple dishes emphasized placing the main ingredient in water to boil along with the necessary condiments. ${ }^{26}$ More significant are other Babylonian recipes which do not simply catalogue the ingredients, but also expound the preparation in detail and at length. Of these, says Bottéro, the double aim was to create a dish with "a taste intelligently achieved and a presentation both recherché and nutritionally rich", 27 a description which perfectly fits the style and purpose of the bulk of the recipes in al-Warrāq and in later culinary manuals of the Arabic corpus. The Babylonian texts, Bottéro concludes, imply a vast "literary" and continuous culinary tradition down to at least $400 \mathrm{BC}$ and probably later. What occurred in the intervening millennium between the Babylonian and Islamic cultures must await further detailed study. One suggestive approach has been a comparison of Greek views of Persian eating habits in the context of the royal court with the contents of the Persepolis Fortification Texts at the time of the Achaemenid empire. ${ }^{28}$ The link between the culinary tradition reflected in al-Warrāq's compilation and the Sassanian (or earlier Persian) past is evident in the number of dishes and ingredients with Persian names. ${ }^{29}$ What is nevertheless clear from this brief survey is that the Arab-Islamic medico-culinary tradition is founded upon the twin bases of Greek humoral theory on the one hand and the indigenous culinary practices of the ancient Near Eastern cultural centres on the other. An interesting illustration of this dual dietetic track in the early "Abbasid period is the Christian court physician, Abū Zakariyya Yuhanna b. Māsawayh (d. 857), to whom is attributed, in addition to his medical writings, a culinary manual. ${ }^{30}$ The relation between culinary (nutritional) and medical aspects of food is expressed in one of his aphorisms which stressed the importance of medicinal nutrients as follows, "We must, wherever possible, treat an organ with a medicament (daw $\bar{a}$ ') which tends to resemble whatever gives nourishment to that organ; thus it is best if that medicament is nourishing (dawā ghidhā' '̀)." 31

Returning to al-Warrāq's Kitāb al-țabikh, he informed his anonymous patron that he had successfully completed his commission to gather together recipes prepared for "kings, caliphs, lords and chiefs" which included as well advice on "the benefits to the body and avoidance of the harmful effects of such dishes". This latter phrase reflects the title of alRāzī's book on dietetics mentioned above. Al-Warrāq's is but one of half a dozen Arabic culinary manuals (edited and published to date) dating from the tenth to thirteenthfourteenth centuries whose provenances range from Iraq to the Iberian peninsula. ${ }^{32}$ Together they comprise a treasury of several thousand recipes reflecting the enormously

\footnotetext{
${ }^{26}$ Bottéro, op. cit., note 24 above, on pp. 250-2.

27 Ibid., p. 254.

${ }^{28}$ Heleen Sancisi-Weerdenburg, 'Persian food: stereotypes and political identity', in Wilkins,

Harvey, and Dobson (eds), op. cit., note 5 above, pp. 286-302.

29 Jack Goody made the connection between Arab cuisine and the earlier Mesopotamian and Persian cultures, but without concrete data, in his Cooking, cuisine and class: a study in comparative sociology, Cambridge University Press, 1982, p. 127; however, some of his observations on medieval Arab cuisine as such must be treated with caution.

${ }^{30}$ Sezgin, op. cit., note 14 above, pp. 231-6; for
}

ibn Māsawayh's dietetic works see numbers, 8, 9, 20, $21,31,37,38$ and for his cookbook, p. 236. Ibn Māsawayh was one of Hunayn b. Ishāq's teachers.

31 Yuhanna ibn Māsawayh (Jean Mesue), Le livre des axiomes médicaux, ed. and trans. Danielle Jacquart and Gérard Troupeau, Geneva, Librairie Droz, 1980, axiom 25 (my translation); see also axioms 13 and 52, and Sezgin, op. cit., note 14 above, p. 233 , no. 1 .

32 D Waines, 'Prolegomena to the study of medieval Islamic culinary culture', Occasional Papers of the School of Abbasid Studies, No.1, 1986, pp. 30-9. 


\section{Dietetics in Medieval Islamic Culture}

rich and varied culinary cultures of the medieval Muslim Middle East. With much justice, Wilkins has observed that "[c]ookery books are ephemeral in world history", ${ }^{33}$ but this is far less true of medieval Arabic-Islamic civilization than of either the classical Greek or indeed any other medieval civilization. Al-Warrāq shared many traits with other cookbook compilers, although he alone included poetry. Despite his claim to have compiled recipes of dishes prepared in court circles, the contents of his work reveal a far wider scope of interest. They embrace the tastes of a broader urban bourgeoisie. In some cases, simple preparations of rural origin were transformed in the urban context, chiefly by the addition of more expensive ingredients; regional variations of a particular dish are also found. Behind the cookbooks as a genre there lies an oral tradition, or traditions, from which the compilers drew their material. The fare depicted in the cookbooks is not, therefore, exclusively a court cuisine but rather one which embraced the households of bureaucrats, scholars, merchants, and the like.

This leads to a more important point for our present purposes. Al-Warrāq's compilation was not restricted to providing his readers simply with recipes of dishes for the daily table. Like other culinary manuals, his reflected a close awareness of contemporary medical views on dietetics. Several of the opening chapters of al-Warrāq's work deal with subjects reflecting the influence of the Greek dietetic tradition. For example, there are discussions on the dishes best suited to young and old (chapter 6); the "strength" of meats and how they may benefit or harm the individual (8); the nature of the various parts of (domestic) animals (9), fish (11), various birds' eggs (12), cereal grains (13), vegetables (14), milk and cheese (15), oils (17), herbs and spices (18-19), fruits (20) and so on. All this information precedes the actual recipes, which are presented according to various types of dish. In a later collection of recipes, dating from thirteenth- or fourteenth-century Egypt, such information is diffused throughout the book, where comments on the benefits of a particular dish are often included along with the recipe itself. ${ }^{34}$

Clearly, information concerning dietetics was not a monopoly of the physicians; it was shared by other sectors of the cultured urban public. Moreover, public awareness of food as a contributor to the individual's health was not confined simply to either professional medical or culinary works. Of significance here is the highly respected scholarly figure of 'Abd al-Malik b. Habīb (d. 853). Born in al-Andalus, he practised as a jurist in Cordoba following a three-year sojourn in Egypt and Mecca where, among his other activities, he gathered material for a medical compendium entitled Mukhtasar fi-l tibb. He dealt with the cure of illness and the preservation of health chiefly by means of food and diet but also noted methods of bleeding, cupping, and magical formulae. Ibn Habib drew upon two distinct sources, the Traditions of the Prophet and the Greek humoral tradition, although in the latter case he mentioned no sources. A brief example from each will suffice. First, the Prophet advised that adding salt to one's food was a remedy against seventy-two ailments, including madness, leprosy, toothache, sore throat and stomach pain. Second, cabbage (kurnub), which had qualities of heat and dryness, when cooked and eaten would dissolve an internal tumour. ${ }^{35}$ This combination of religious belief and "rational" medical

\footnotetext{
33 Wilkins and Hill, op. cit., note 5 above, p. 431.

${ }^{34}$ See Kanz al-fawà'id fí tanwì al-mawà'id, ed. Manuela Marín and David Waines, Bibliotheca Islamica, Band 40, Stuttgart and Beirut, Franz
}

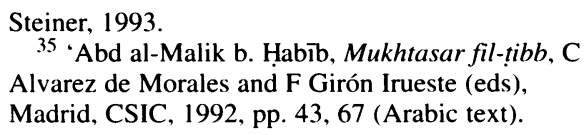




\section{David Waines}

lore associated with food was evidently widespread by the middle of the ninth century. Further examples may be cited. Two late ninth- or early tenth-century encyclopaedias, which sought to inform bureaucrats and the broader reading public on a range of useful subjects, each contained sections on food and drink; one by Ibn Qutayba (d. 889) was written in the eastern Islamic domains, while the other by Ibn 'Abd Rabbihi (d. 940) was composed in al-Andalus. ${ }^{36}$ During the same period (AD 870-915), the standard collections of Traditions from the Prophet Muhammad were being compiled in which the topics of food and drink are also treated. The earliest agronomical work in Arabic on 'Nabatean agriculture', attributed to Ibn Wahshiyyah and produced between 903 and 930, contains medical and culinary uses for many of the 360 plants dealt with in this monumental treatise. ${ }^{37}$ Like other physicians, al-Rāzi contributed to the public's understanding of medical theory with an introductory work on the subject. ${ }^{38}$ This "semi-popular" work was distinct from his more formal manual of guidance for medical practitioners and his private "medical study-files" as Iskandar has described his great work the Kitāb al-Hāât 'Continens'. ${ }^{39}$ He also left a small book entitled Man lā yahdaruhu tabib, 'What to do in the doctor's absence', aimed at a non-professional audience. ${ }^{40} \mathrm{Al}$-Rāzì once commented that there was nothing more dangerous than an ignorant physician attending a patient; perhaps his intention was to inform a public with the means of defending itself against such eventualities. ${ }^{41}$

The picture presented thus far is of an emerging medico-culinary or, more precisely, dietetic tradition, appearing as an open and informed relationship between medical and culinary concerns for the daily consumption of food. The theoretical aspect of this tradition was, as already noted, based upon the inherited forms of classical medicine while its culinary content was founded upon indigenous cooking cultures of the Middle East, some of which are explicitly identified as Arab, Persian, Berber and, in rare instances, Christian $^{42}$ or Jewish. Not surprisingly, attitudes toward certain foods differ from those of the Greco-Roman world. Some are obvious. The Roman love of pork is met by its outright prohibition in Muslim culture, a taboo shared too by Jewish communities. The Muslim prohibition of alcohol is more complex and is one which I have discussed elsewhere and

\footnotetext{
${ }^{36}$ Ibn Qutayba, 'Uyūn al-Akhbār, ed. Aḥmad Amīn, Cairo, Dār al-Kutub, 1925-30; Ibn ‘Abd Rabbihi, 'Iqd al-farìd, ed. Aḥmad Amīn, et al., Cairo, Dār al-Kutub, 1940. Haskell Isaacs mentions a popular genre of medical literature (tibb al-'ämmah) which was written in the belief that "as far as possible, all knowledge should be available to anyone who seeks it. Evidence of such literature is found among the many medical fragments of the Cairo Geniza." See his 'Arabic medical literature', in Young, et al. (eds), op. cit., note 15 above, pp. $342-63$, on p. 348.

${ }^{37}$ L'agriculture nabatéenne, al-Filāha alNabitiya, ed. Toufic Fahd, Damascus, Institut Français de Damas, 2 vols, 1993-95. The present writer is preparing a study on the contribution of the agronomical works to the medico-culinary tradition.

${ }^{38}$ Kitāb al-madkhal ila sinā 'at al-tibb wa huwa isāghāji. Libro de la introducción al arte de la
}

medicina o 'Isagoge', ed. and trans. $\mathrm{M}$ de la $\mathrm{C}$ Vázquez de Benito, Universidad de Salamanca, 1979. See Sezgin, op. cit., note 14 above, 284, no. 6.

39 A Z Iskandar, 'The medical biography of alRāzì’, in G Hourani (ed.), Essays on Islamic philosophy and science, Albany, SUNY Press, 1975, pp. 41-6.

40 Sezgin, op. cit., note 14 above, p. 287 , no. 21 . The title is identical to that of a work by Rufus of Ephesus, ibid., p. 64.

41 A Z Iskandar, A catalogue of Arabic manuscripts on medicine and science in the Wellcome Historical Medical Library, London, Wellcome Historical Medical Library, 1967, p. 4.

${ }^{42}$ On a case of likely borrowing from Christian sources, see D Waines and M Marín, 'Muzawwar: counterfeit fare for fasts and fevers', Der Islam, 1992, 69 (2): 289-301. 


\section{Dietetics in Medieval Islamic Culture}

hence will not dwell upon here. ${ }^{43}$ Other attitudes are more difficult to detect, owing largely to our as yet sketchy knowledge of pre-Islamic Middle Eastern culinary traditions which could be used to compare with the abundant data surviving from Islamic times. ${ }^{44}$

Nevertheless, one contrast does appear to concern vegetables. Archestratus, for example, deprecates vegetable dishes in three surviving fragments of his poem, and Celsus ranks vegetables in the categories of middle and weak nourishment rather than in that of the strongest. Moreover, in the Arabic translation of Galen's dietetic work, Kitāb al-aghdhiyya, all vegetables are described as producing poor quality blood and in small quantities; therefore, they contribute little nourishment to the body. ${ }^{45}$ In the following discussion attention will be given to the use of vegetables in the Arabic dietetic and culinary works.

\section{Vegetables in the Islamic Medico-Culinary Tradition}

The use of vegetables as described in the Arabic culinary corpus occurs in more complex preparations than those, for example, attributed to Apicius. Moreover, vegetables are accorded a higher regard, as witnessed in dishes with meat named after a particular vegetable ingredient, such as Isfānākhiyya (spinach), Kurnubiyyah (cabbage), and Saljamiyyah (turnip). By comparing the medical, dietetic view of individual vegetables with the culinary use of the same plants, not only can fresh light be thrown upon their use but also upon the relationship between professional medical opinion on dietetics and lay dietary practice in the household.

One example is the cultivated variety of carrot (jazar, which could also refer to the parsnip) which is described in medical dietetic sources using Galenic categories as hot and moist, and a wild variety (shaqāqil) as hot and dry. Several properties were attributed to the cultivated type: it could be a diuretic, an emmenagogue when cooked with water and honey, ${ }^{46}$ and an aphrodisiac. ${ }^{47}$ Among its benefits were mentioned stimulation of the appetite, and if eaten either before or after meals it aided digestion; it also helped to remove obstructions from the liver and spleen. However, if the carrot were eaten raw, as animals do, it created wind and could be digested only slowly; moreover, its frequent consumption produced impure blood. Dietetic information, however, was not limited to the qualities and properties of a particular food-stuff. The medical view was also concerned with the food's proper preparation, thereby permitting adequate digestion and avoidance of harm to the body. To avoid the ill effects of carrots one should boil them thoroughly and then cook them with meat, fresh coriander, onion, pepper, oil, caraway and

\footnotetext{
${ }^{43}$ See D Waines, 'Abū Zayd al-Balkhī on the nature of forbidden drink: a medieval Islamic controversy', in M Marín and D Waines (eds), $L a$ alimentación en las culturas islámicas, Madrid, AECM, 1994, pp. 111-26.

44 Another, related problem, which cannot be dealt with in this essay, is that where in the Arabic dietetic and culinary sources evidence of humoral theory is present, where a plant is described in terms of the four qualities, hot, cold, dry or moist, it may not follow that the Muslim authors ascribe to it the same
}

benefit or harm as that found in the Greek literature. This requires patient comparison of sources.

45 Nina Garbutt, 'The Kitāb al-aghdhiya of Hunayn b. Ishāa: a critical study', PhD thesis, Cambridge University, 1997, p. 91.

46 Ibn Habib, op. cit., note 35 above, p. 68 (Arabic text). See also al-Isrā'ilī, op. cit., note 20 above, vol. 3, p. 108.

${ }^{47}$ Abū Marwān 'Abd al-Malik b. Zuhr (d.1162), Kitāb al aghdhiyya, ed. and trans. E García Sánchez, Madrid, CSIC, 1992, p. 59 (Arabic text). 


\section{David Waines}

sweet vinegar or sugar. ${ }^{48}$ Or, after boiling, they could be eaten with vinegar and murrì, itself another prepared condiment. ${ }^{49}$ In this latter form carrots could be eaten either before or during the meal. ${ }^{50}$

The preparation with meat just noted corresponds closely to an actual dish, the famous meat stew of Persian origin, called sikbāj. One recipe for it contains carrot and other vegetables boiled beforehand and added to the pot in which the meat cooks with fresh coriander and other seasonings; at a secondary stage vinegar and honey are added in balanced measure to give the dish its characteristic sweet-sour flavour. ${ }^{51}$ This sikbāj recipe is too similar to the dietetic preparation to be coincidental. Other specific preparations, too, are mentioned in the dietetic treatises for the particular purpose of aiding, adjusting or altering an individual's current condition.

There does not exist, however, a medical opinion on the culinary use of every vegetable. For one thing, the dietetic treatises cover a much wider range of plants than that found in culinary preparations. Some of these plants even remain unidentified. Medical opinion was also frequently unclear as to which variety of a given plant was best suited for medicinal or more strictly culinary purposes. However, in the case of hindab $\bar{a}$ (chicory/endive) some medical views ${ }^{52}$ suggested that it was better used for medicinal than nutritional purposes, which may explain its single appearance in one cookery book and then only for use in the medicinal beverage sakanjabin, the classical oxymel. ${ }^{53}$ Nor is there always a correspondence between medical and culinary applications. A medical view of fenugreek ( $h u l b a$ ), for example, was that a decoction of the plant helped to clear the lungs and chest of heavy, moist and possibly corrupting humours. ${ }^{54}$ In the culinary context, however, the only cooking hint given suggested that if meat that was high was first boiled in water with a bit of fenugreek and then cooked again in fresh water it would taste as if it had been freshly slaughtered. In the case of asparagus (hilyün), it was medically considered very nourishing with properties of a diuretic, and the ability to unblock the liver and spleen, and to break up kidney stones. ${ }^{55}$ Nevertheless, the plant is not found in the major late culinary work, Kanz al-fawà'id, and only two recipes call for its use in the earliest Kitāb al-tabikh by al-Warrāq, both attributed to the cookbook of the 'Abbasid prince and onetime Caliph, Ibrāhīm b. al-Mahdī (d. 857).

\footnotetext{
${ }^{48}$ Al-Isrā'îlī, op. cit., note 20 above, vol. 3, p. 108 .

${ }^{49}$ Al-Rāzī, op. cit., note 19 above, p. 40. See also, D Waines, 'Murri: the tale of a condiment', alQantara, 1991, 12 (2): 371-88.

${ }^{50}$ Ibn Zuhr, op. cit., note 47 above, p. 67 (Arabic text). The most complicated preparation for carrot in the Latin work attributed to Apicius, The Roman cookery-book, p. 91, is "Boil the carrots and chop. Then cook in cumin-sauce with a little oil and serve. Make the cumin-sauce as for cabbage." Possibly this suggests a more modest household status in which the dish was consumed than the more expensive and sophisticated dishes in the Arabic tradition.

${ }^{51}$ Kanz al-fawa'id, op. cit., note 34 above, recipe no. 7 .
}

\footnotetext{
52 Al-Isrā'î̀ī, op. cit., note 20 above, vol. 3, p. 27; see also al-Rāzī, op. cit., note 19 above, p. 35.

${ }^{53}$ Kanz al-fawä'id, op. cit., note 34 above, recipe no. 363. On this preparation see, M Marín and D Waines, 'Ibn Sina on sakanjabin', Bulletin des études orientales, 1995, 47: 81-97.

${ }^{54}$ This is the later view of Dä' ūd b. 'Umar alAntākī (d. 1599) in his Tadhkira Üla al-albāb,

Beirut, al-Maktaba al-Thaqafiyya, n.d., vol. 1, p. 126. Ibn Habỉb, op. cit., note 35 above, p. 46 (Arabic text) cites a tradition from the Prophet praising the curative power of fenugreek which was, figuratively, worth its weight in gold.

55 Ibn Habib, op. cit., note 35 above, p. 68 (Arabic text); al-Rāzī, op. cit., note 19 above p. 38; al-Isrā'îī, op. cit., note 20 above, vol. 3 , pp. 106-8.
} 


\section{Dietetics in Medieval Islamic Culture}

The case of eggplant or aubergine, however, is instructive. It was unknown to the Greco-Roman kitchen since it was a "new plant" which had travelled westward from India and, in Islamic times, from Persia through Arab lands and North Africa. ${ }^{56}$ Although commonly found in the culinary manuals, some medical opinion addressed the possible ill effects on the body caused by its production of black bile; ${ }^{57}$ the doctors' preoccupation was with its proper preparation: cutting the vegetable in half, salting it and leaving it a while in warm water, and using several changes of water to remove the impurities. It could then be boiled and cooked with meat or, without meat, boiled and then fried to ensure its safe use. ${ }^{58}$ The recipes in the cookery books follow these very procedures. In this instance it is even likely that the medical view was informed by actual cooking practices which travelled westward along with the plant.

On the other hand, recipes for daily dishes are found in the culinary manuals for which a specific dietetic purpose is mentioned. Among them was the subject of sexuality since, according to some medical views, coitus was one of the so-called "non-naturals" which affected the body's health and therefore fell within the individual's general regimen for well-being. For example, an omelette preparation of egg, onion, oil, mastic, cinnamon and a pinch of salt was said to stimulate the sexual appetite. ${ }^{59}$ Other examples of the use of vegetables in regimen will be noted shortly. Another purpose altogether for plant use is the case of nammäm, a variety of mint or thyme. Included among the seasonings for a widely popular dish called $k i s h k,{ }^{60}$ it is more frequently mentioned in recipes for incense and perfume. ${ }^{61}$ Pleasant smells, in both the domestic surroundings and on one's body and clothing (not to mention cooked dishes as well) were judged part of proper household management and personal hygiene; additional recipes for soap and toothpaste indicate the importance of the culinary manuals in any study of medieval urban domestic affairs. ${ }^{62}$ Here, however, is the appropriate moment to take stock of certain points suggested by this brief survey of medical and culinary material.

It has been observed of the pre-modern age that medicine could only have functioned as a dialogue between physicians and their patients, for "without a common language, the enterprise would have juddered to a halt". ${ }^{63}$ We have alluded above to a public interest in food and drink expressed in Traditions from the Prophet Muhammad, encyclopaedic literary works, introductory "texts" on medicine, and culinary manuals. A pool of knowledge on dietetics existed and was shared by both doctor and layman. The literary sources were almost certainly complemented by discussion and debate among professionals and laymen, both separately and together. The dialogue, founded upon a

\footnotetext{
56 Andrew M Watson, Agricultural innovation in the early Islamic world, Cambridge University Press, 1983, pp. 70-1.

${ }^{57}$ Ibn Habib, op. cit., note 35 above, p.68 (Arabic text); Ibn Zuhr, op. cit., note 47 above, p. 56 (Arabic text).

${ }^{58}$ Al-Isrā'î̀i, op. cit., note 20 above, vol. 3, p. 147; see also al-Rāzī, op. cit., note 19 above, p. 37.

${ }^{59} \mathrm{Kanz}$ al-fawā'id, op. cit., note 34 above, recipe no. 188.

${ }^{60}$ See Françoise Aubaile-Sallenave, 'Al-kishk: the past and present of a complex culinary practice', in S Zubaida and R Tapper (eds), Culinary cultures of the Middle East, London, I B Tauris, 1994, pp.
}

105-39. For a discussion of the medical uses of kishk, see

p. 129.

${ }^{61}$ Kanz al-fawā'id, op. cit., note 34 above, recipe nos., 694, 706, 713, 715.

62 For a suggestive essay along these lines, see M Marín, 'Beyond taste: the complements of colour and smell in the medieval Arab culinary tradition', in Zubaida and Tapper (eds), op. cit., note 60 above, pp. 205-14.

${ }^{63} \mathrm{R}$ and D Porter, In sickness and in health: the English experience 1650-1850, London, Fourth Estate, 1988, p. 137. 


\section{David Waines}

common language, is mirrored in the texts we have been considering. The subject of dietetics covered many aspects related to the individual's physical well-being: how to follow due measure in one's daily nourishment and avoid extremes; which foods by their nature were contrary to or compatible with the individual's own constitution, or, how to avoid the ill effects of foodstuffs by appropriate correction and adjustment in their preparation; which ingestibles (vegetables being our present concern) or which dishes were suitable for counteracting a variety of ailments like fevers, or were suitable for dealing with particular conditions such as an excess of bile or phlegm, or which could stimulate a desired effect, like a diuretic.

From the layman's point of view, dietetics dealt with day-to-day matters of health in the home. One has to recognize, however, that cases of indisposition and of "dis-ease" dealt with in the household were restricted to those matters which would not normally require the physician's expert knowledge of drugs and their administration, this being considered a more advanced and specialized level of therapeutics best left to the professional. From the doctor's viewpoint, the principle of a sound diet was based on moderation in consumption and balance in the qualities of foods consumed. Common sense, custom and experience informed the viewpoints of physician and layman alike, which made dialogue possible. Experience was contributed from both sides, inherited medical lore coupled with the inherited lore of food-stuffs and cooking, each allowing for possible modification of and/or addition to the dietetic tradition. The physician, however, was not the sole source of authority in dietetic matters, but he was rather a partner with members of the educated lay public. The partnership may be exemplified by the appearance in the culinary manuals of a variety of "home remedies" which clearly had the physicians' stamp of approval but which were left to the household domain for their preparation and application. Let us now turn to some examples of these preparations.

\section{Home Remedies}

The first example is a dish called muzawwar. ${ }^{64}$ The word means "counterfeit" or "fake" and when applied to food could be taken to mean a preparation which was a simulation of something else. The muzawwar dishes probably entered the Islamic medico-culinary tradition from indigenous Christian communities (possibly Nestorian) where they were prepared for days or periods of fasting and hence did not contain meat. Thus they imitated or simulated meat dishes which were permissible on non-fasting days. It was possible to prepare imitations of well-known and popular meat dishes in the medieval cuisine, like sikbāj and madirah, in which not only meat was excluded but also animal cooking fat was replaced by the expressed oil of sesame seeds or almonds. These meatless preparations, however, underwent a transformation of purpose in Islamic times. As vegetarian preparations, they were adopted for medicinal purposes. Among a list of definitions of medical terms there occurs that of muzawwar which is described as "all nourishment prepared for an ill person which contains no meat". 65

In the earliest extant culinary manual of al-Warrāq, two muzawwar recipes are attributed to the Christian physician Ibn Māsawayh (d. 857), who is possibly the one who introduced

64 The following discussion is based upon the article by Waines and Marín, op. cit., note 42 above.

${ }^{65}$ Ibid., p. 290, fn. 3. 


\section{Dietetics in Medieval Islamic Culture}

the notion of a medicinal use of these vegetarian preparations into the Islamic dietetic tradition. Several preparations are designed to treat a person with fever or of a bilious constitution. Using a variety of marrow (qar'ah) cooked with onion, fresh spices and sesame seed oil, a combination of rose water, celery seeds, sour grape juice and sugar was then sprinkled over the cooked ingredients. ${ }^{66}$ Medical opinion of the main ingredient, marrow, was that by nature it was cold and thus suited for those suffering from fever and an excess of yellow bile. ${ }^{67}$ Spinach (isfānākh) was another favourite ingredient of the muzawwar dishes. Some physicians judged the vegetable to be very nourishing and suitable for those of both hot and cold constitution. ${ }^{68}$ It was employed in a meat dish, Isfänäkhiyyah, named after the vegetable, but in its counterfeit variety it was used for those with fever caused by an excess of yellow bile, or for those suffering from an inflamed liver or, indeed, for ailing bodies in general. Muzawwar recipes using pomegranate seed, also described as cold and dry in dietetic texts, seem more versatile: they not only coped with fever and burning kidneys, but also benefited stomach upsets and, more remarkably, fear and heart pain. Lastly, we may note a muzawwar preparation from one of the cookery books of Andalusi origin in the Iberian peninsula which displays as much compassionate concern for the sick as remedial purpose: the title of the recipe reads, "A dish made from marrow which appears to resemble fish with which one could deceive a sick person who has a strong desire for fish . . ." ${ }^{69}$ In the specialist medical text ascribed to Thäbit b. Qurrah (d. 901) reference is made to muzawwar preparations for the treatment of headaches and fevers. ${ }^{70}$

To conclude this section attention will now be given to what the Arabic medical texts refer to as "medicinal nutrients" (ghidhā' dawä'i) but which are simply varieties of "home remedies" as described in the cookery-books. A medicinal nutrient was considered a food whose effect upon the body was evident before it had been fully digested, that is a substance which at first overcame the body and was then overcome by it. ${ }^{71}$ By ordinary "nutrients" (ghidhä') are meant food and drink in the broadest sense, which the body transforms into its own substance although the effect of this transformation may not be immediately evident but which nevertheless contributes to the body's growth. The medicinal nutrient, therefore, contributed to bodily growth, but initially was able to correct some imbalance in the individual's normal temperament or constitution.

Medical advice was followed in the domestic household where the culinary manuals indicate preparations for several kinds of medicinal nutrients. These include vegetable potions called sharāb, electuaries (ma‘jūn), stomachics (jawärish), medicinal powders (sufüf) and fruit juices $(r u b \bar{u} b)$. They shared certain general characteristics. They were relatively simple both in terms of their ingredients and preparation; if desired, most could be prepared and stored for future use; they were intended for specific restorative purposes, unlike certain daily dishes recommended for their balanced nourishment and suitable for persons of every

${ }^{66}$ Kitāb al-tabikh, op. cit.. note 22 above, pp. 119-24, 281-4.

${ }^{67}$ Ibn Habīb, op. cit., note 35 above, p. 67 (Arabic text); al-Rāzī, op. cit., note 19 above, p. 38; alIsrā'îlí, op. cit., note 20 above, vol. 3, pp. 19-20; Ibn Zuhr, op. cit., note 47 above, pp. 56-7 (Arabic text).

${ }^{68}$ Al-Rāzī, op. cit., note 19 above, p. 39; alIsrā'îlī, op. cit., note 20 above, vol. 3, p. 81 .

${ }^{69}$ A Huici Miranda (ed.), La cocina Hispano-
Magrebi en la España Almohade, Madrid, Instituto de Estudios Islámicos, 1965, p. 171.

${ }^{70}$ George Sobhy (ed.), The book of the Dhakhira, Cairo. The Government Press, 1928, p. 19, and ch. 26 on fevers.

${ }^{71}$ See D Waines, 'Sugar in Andalusi "home remedies", in 1492: Lo dulce a la conquista de Europa, Motril, Diputación Provincial de Granada. 1994, pp. 77-86. 


\section{David Waines}

temperament; and, except the powders, each contained a sweetening agent, sugar or honey. ${ }^{72}$ Some of these remedies were sold in the market by specialist producers, although the differences between the commercial and domestic product can only be guessed at. Possibly the commercial products were more complex and therefore more expensive than those made up in the home, although price should not have been a major concern in the households where they were confected. The existence of the domestic variety possibly reflected the householders' reluctance to purchase from the market goods thought to be of dubious quality. Without going into the detail of their preparation, ${ }^{73}$ we can note some of their uses. Sharāb, for example, was intended to remedy blockages in the kidneys, clean the stomach of excess phlegm, alleviate fever, dissolve fats in all parts of the body, and bring joy to the heart. Electuaries, whose benefits were broadly similar to the stomachics, were in addition said to strengthen sexual desire, increase semen, stimulate the appetite and digestion, alleviate an excess of yellow bile in the stomach and act as a diuretic or emmenagogue. An increase in one's general sense of well-being is common to several of the remedies.

\section{Conclusion}

Bringing this discussion to a close, we return to a point raised at the start, namely, the relationship between the "medical" and "culinary" arts alluded to by the Hippocratic author of the Tradition in medicine. In early Islamic times, inherited Greek dietetic theory was wedded to indigenous Middle Eastern culinary traditions, textual evidence for which may be traced to Babylonian times. A dialogue between medical professionals and laymen emerged, each group to some extent informing and being informed by the other. The culinary manuals provide a clue to the nature of this relationship. They point to the central place of the domestic household in the life of the leisured urban class in Islamic societies, where not only proper nourishment could be provided to its members but also remedies for minor ailments or disorders which did not initially, at least, require the physician's expert knowledge of drugs to combat more serious disorders. Healthy food habits were a primary concern of both physicians and household managers, yet the daily supervision of such management was possible with minimum intervention from the physician. The physician al-Rāzì noted that "providing Nature can efficiently combat disease, the assistance of physicians will not be required." 74 Nevertheless, it was understood that assisting Nature was in the first instance within the competence of the household; there it was possible to draw upon the range of home remedies available for fevers and other minor upsets. This attitude was, moreover, reflected in the popular saying by which the Arabs, including their women, were said to have summarized their understanding of medicine, namely, that "the stomach is the abode of disease, and abstaining from injurious foods is the principal part of medicine". 75

\footnotetext{
72 On the medical importance of sugar, see M Marín and D Waines, 'The balanced way: food for pleasure and health in medieval Islam', Manuscripts of the Middle East, 1989, 4: 123-32.

${ }^{73}$ Recipes for preparations of maj ‘ūn, jawārish, and sharāb are found in the Index of the Kanz alfawä'id, op. cit., note 34 above.

${ }^{74}$ Iskandar, op. cit., note 41 above, p. 4.

${ }^{75}$ The Shu'übiyya in al-Andalus: the risala of Ibn
}

García and five refutations, trans. James Monroe, Berkeley, University of California Press, 1970, p. 86. The quotation appears in the fourth refutation of Ibn García by Abū al-Tayib 'Abd al-Mun 'im Ibn Mann Allāh al-Qarawī (d. 1099), who also cites the Prophet Muhammad as saying that "The origin of every disease is indigestion". Despite the polemical context of these citations, they can still be said to reflect widely known, popular viewpoints. 